\title{
Sample pooling for real-time PCR detection and virulence determination of the footrot pathogen Dichelobacter nodosus
}

\author{
Sara Frosth ${ }^{1,2}$ (1) - Ulrika König ${ }^{3}$ - Ann-Kristin Nyman ${ }^{4}$ Anna Aspán ${ }^{2}$
}

Received: 12 January 2017 / Accepted: 15 March 2017 /Published online: 25 March 2017

(C) The Author(s) 2017. This article is published with open access at Springerlink.com

\begin{abstract}
Dichelobacter nodosus is the principal cause of ovine footrot and strain virulence is an important factor in disease severity. Therefore, detection and virulence determination of $D$. nodosus is important for proper diagnosis of the disease. Today this is possible by real-time PCR analysis. Analysis of large numbers of samples is costly and laborious; therefore, pooling of individual samples is common in surveillance programs. However, pooling can reduce the sensitivity of the method. The aim of this study was to develop a pooling method for real-time PCR analysis that would allow sensitive detection and simultaneous virulence determination of $D$. nodosus. A total of 225 sheep from 17 flocks were sampled using ESwabs within the Swedish Footrot Control Program in 2014. Samples were first analysed individually and then in pools of five by real-time PCR assays targeting the $16 \mathrm{~S} r R N A$
\end{abstract}

Sara Frosth

sara.frosth@slu.se

Ulrika König

ulrika.konig@gardochdjurhalsan.se

Ann-Kristin Nyman

ann.nyman@sva.se

Anna Aspán

anna.aspan@sva.se

1 Department of Biomedical Sciences and Veterinary Public Health, Swedish University of Agricultural Sciences, P. O. Box 7036, SE-750 07 Uppsala, Sweden

2 Department of Microbiology, National Veterinary Institute (SVA), SE-751 89 Uppsala, Sweden

3 Farm and Animal Health, Kungsängens gård, SE-753 23 Uppsala, Sweden

4 Department of Animal Health and Antimicrobial Strategies, National Veterinary Institute (SVA), SE-751 89 Uppsala, Sweden and aprV2/B2 genes of D. nodosus. Each pool consisted of four negative and one positive $D$. nodosus samples with varying amounts of the bacterium. In the individual analysis, 61 $(27.1 \%)$ samples were positive in the $16 S r R N A$ and the aprV2/B2 PCR assays and 164 (72.9\%) samples were negative. All samples positive in the aprV2/B2 PCR-assay were of aprB2 variant. The pooled analysis showed that all 41 pools were also positive for $D$. nodosus $16 S$ rRNA and the aprB2 variant. The diagnostic sensitivity for pooled and individual samples was therefore similar. Our method includes concentration of the bacteria before DNA-extraction. This may account for the maintenance of diagnostic sensitivity. Diagnostic sensitivity in the real-time PCR assays of the pooled samples were comparable to the sensitivity obtained for individually analysed samples. Even sub-clinical infections were able to be detected in the pooled PCR samples which is important for control of the disease. This method may therefore be implemented in footrot control programs where it can replace analysis of individual samples.

Keywords Dichelobacter nodosus $\cdot$ Ovine footrot $\cdot$ Pooling of samples $\cdot$ Real-time PCR $\cdot$ Virulence $\cdot \operatorname{aprV2/B2}$

\section{Introduction}

Dichelobacter nodosus, a fastidious Gram-negative bacterium, is the principal cause of ovine footrot (Beveridge 1941; Kennan et al. 2011). This is a transmissible disease that affects the epidermis of the feet and often results in lameness (Beveridge 1941). The disease has a worldwide occurrence in sheep and the economic impact on the sheep industry is substantial in terms of production losses and costs for treatment and prevention (Bennett and Hickford 2011; Green and George 2008; Marshall et al. 1991). Disease severity can 
range from inflammation of the interdigital skin (benign footrot) to complete underrunning of the hoof horn (virulent footrot) (Beveridge 1941; Egerton et al. 1969). The virulence of the infecting $D$. nodosus strain is an important factor for disease severity (Stewart et al. 1986). Two separate variants of the bacterium - virulent and benign — have recently been demonstrated by whole genome sequencing, and they have been shown to correlate with presence of aprV2 and aprB2, respectively (Kennan et al. 2014). The presence of virulent and benign strains varies between countries; virulent strains are the most common variant in UK sheep (Maboni et al. 2016; Moore et al. 2005) while benign strains predominate in Swedish sheep (Frosth 2016). Inconsistencies between $D$. nodosus virulence and clinical signs have also been reported (Frosth et al. 2015; Moore et al. 2005; Stäuble et al. 2014b).

Detection and virulence determination of $D$. nodosus can today be achieved by real-time PCR analysis (Frosth et al. 2015; Frosth et al. 2012; Stäuble et al. 2014a). As analysis of a large number of samples may be required for an accurate diagnosis in large sheep flocks or to establish that a flock is free of footrot; this is both time consuming and costly. Therefore, pooling of individual samples is a common strategy of surveillance programs and is implemented, for example, in the Swedish Control Programs for Salmonella and Campylobacter (National Veterinary Institute 2016). However, pooling of samples can lead to a reduction in diagnostic sensitivity and should be evaluated before it is used. Hence, the aim of this study was to develop and evaluate a pooling method for real-time PCR analysis that would allow sensitive detection and simultaneous virulence determination of $D$. nodosus.

\section{Materials and methods}

A total of 225 sheep from 17 flocks were sampled at routine inspections within the Swedish Footrot Control Program (Farm and Animal Health 2016) in September 2014. All feet were clinically examined and scored according to the footrot scoring system described by Stewart and Claxton (1993). Six flocks were considered affected by footrot and eleven flocks healthy or unaffected, according to the Swedish definition of footrot as a score $\geq 2$ lesions. ESwabs (Copan Innovation Ltd., Brescia, Italy) were used to sample the interdigital skin of one foot per sheep. The swabs were sent to the National Veterinary Institute (SVA) by regular mail where they arrived within 13 days. There the swabs were shaken on a Thermomixer Comfort (Eppendorf, Hamburg, Germany) for 5 min at 700 $800 \mathrm{rpm}$ to evenly distribute bacteria in the transport medium; samples were then divided into two aliquots of $400 \mu \mathrm{l}$ each. One aliquot was subjected to DNA-extraction on the EZ1 Advanced (Qiagen, Hilden, Germany) after a pretreatment step that included centrifugation (Frosth et al. 2012). In short, the bacteria were pelleted by centrifugation for $5 \mathrm{~min}$ at $13000 \mathrm{~g}$ and lysed by G2-buffer (Qiagen), proteinase K (Qiagen) and heat before automated DNA-extraction. The extracted DNA was used for detection and virulence determination of D. nodosus (16S rRNA and aprV2/B2 genes, respectively) by real-time PCR assays as described in Frosth et al. (2015). Amplification was performed in an Applied Biosystems 7500 Fast Real-Time PCR System (Thermo Fisher Scientific Inc., Waltham, MA, USA) and the results were analysed with the 7500 software v2.0.6 using a manually set threshold of 0.1. Samples were defined as positive if they generated probe-specific fluorescent signals of quantification cycle $(\mathrm{Cq})<40$. This reflects the GLP in the diagnostic laboratory at SVA, were Cq-values between 38 and 40 are regarded as indicative of a possible presence of the bacterium, and the clinical veterinarian is in this case advised to do repeated sampling in the flock to confirm or rule out the diagnosis. Thus, loss of sensitivity even at these high Cq-values is undesirable, and was therefore included in the evaluation of the performance of the pooling method. Presence of either aprV2 (virulent) or aprB2 (benign) genes was counted as a positive outcome in the virulence PCR.

After determining which individual samples were positive or negative for $D$. nodosus, the other $400-\mu l$ aliquots from each sample were pooled in groups of five, comprising four negative and one positive $D$. nodosus samples. Based on the Cq-values obtained in the aprV2/B2 PCR-assays for each individual sample, the pooled samples were divided into three categories; high, intermediate or low amounts of $D$. nodosus added to the pool (high $=\mathrm{Cq}<25 n=10$; intermediate $=\mathrm{Cq}$ $25-29.9 n=21$; and low $=\mathrm{Cq} \geq 30 n=10$ ). Either of the two PCR-assays, aprV2/B2 or 16SrRNA, could have been used for estimation of the amount (high, intermediate or low) of $D$. nodosus in the samples. The aprV2/B2 assay was chosen since it is the slightly less sensitive of the two, possibly due to a lower copy number in the genome; if it worked this would ensure that the pooling would work well for either assay. The pooled samples were centrifuged and subjected to DNAextraction and PCR amplification as for the individual analysis. The only difference from the individual sample handling was that the starting volume of the transport medium was $2 \mathrm{ml}$ instead of $400 \mu \mathrm{l}$. The individual analysis of each sample was performed on the same day that the samples arrived at the laboratory whereas the aliquots intended for pooling were stored at $4{ }^{\circ} \mathrm{C}$ until used. The majority of the positive D. nodosus aliquots were pooled and analysed on the same day as the corresponding individual analysis, but some of the aliquots and especially negative ones were, for practical reasons, stored for up to six days prior to the pooled analysis. The descriptive statistics (as box-and-whisker graphs) were made in Stata statistical software (StataCorp LP; Release 13.1; College Station, TX, USA). 


\section{Results}

In the individual analysis, 61 (of 225, 27.1\%) samples were positive in the $16 \mathrm{~S} r R N A$ and the aprV2/B2 PCR assays and 164 (of 225, 72.9\%) samples were negative in both. All samples positive in the aprV2/B2 PCR-assay in this study were of aprB2 variant (benign). Quantification cycle values for the 41 $D$. nodosus positive samples that were later pooled with negative samples can be seen in Figs. 1a and d. On flock level, D. nodosus was detected in $8(47.1 \%)$ of the 17 flocks. Of these 8 flocks, 6 had clinical signs of footrot whereas 2 flocks had been assessed as healthy or unaffected.

In the pooled analysis, where a single $D$. nodosus positive sample was combined with four negative ones, all 41 were positive in both real-time PCR assays (Figs. $1 \mathrm{~b}$ and e). A comparison of the Cq-values from the individual and pooled analysis for each sample showed an average difference of $-1.1 \mathrm{Cq}$-value for the $16 S r R N A$ gene and -1.2 for the aprB2 gene (Fig. $1 \mathrm{c}$ and f).

\section{Discussion}

Pooling of swab samples for real-time PCR can provide costeffective yet sensitive detection and virulence determination of $D$. nodosus. The pooling method developed in this study can be used as a diagnostic tool in footrot control programs and can be particularly useful in sheep flocks with unclear clinical signs. Eleven of the 17 flocks in our study were judged as healthy, but our method was able to detect $D$. nodosus in 2 of them. These two flocks have been inspected twice since sampling, after one and two years respectively, and they have not developed any clinical signs. The method is currently being used within the Swedish Footrot Control Program in all flocks with clinical signs of footrot and in all newly enrolled sheep flocks regardless of clinical signs due to the results of this study (National Veterinary Institute 2016).

Pooling of individual samples is commonly used to monitor diseases at flock level (National Veterinary Institute 2016). In spite of this, there are few publications on the subject, although it is important that methods used in practice should be thoroughly evaluated. A disadvantage with pooling is that a positive sample can be diluted if mixed with samples negative for the disease-causing agent, leading to a reduction in diagnostic sensitivity. In this study, the diagnostic sensitivity of the pooled and individual samples was the same, which was probably due to the concentration step that we implemented prior to bacterial lysis and DNA-extraction. The concentration step consisted of centrifugation and it was performed on both the
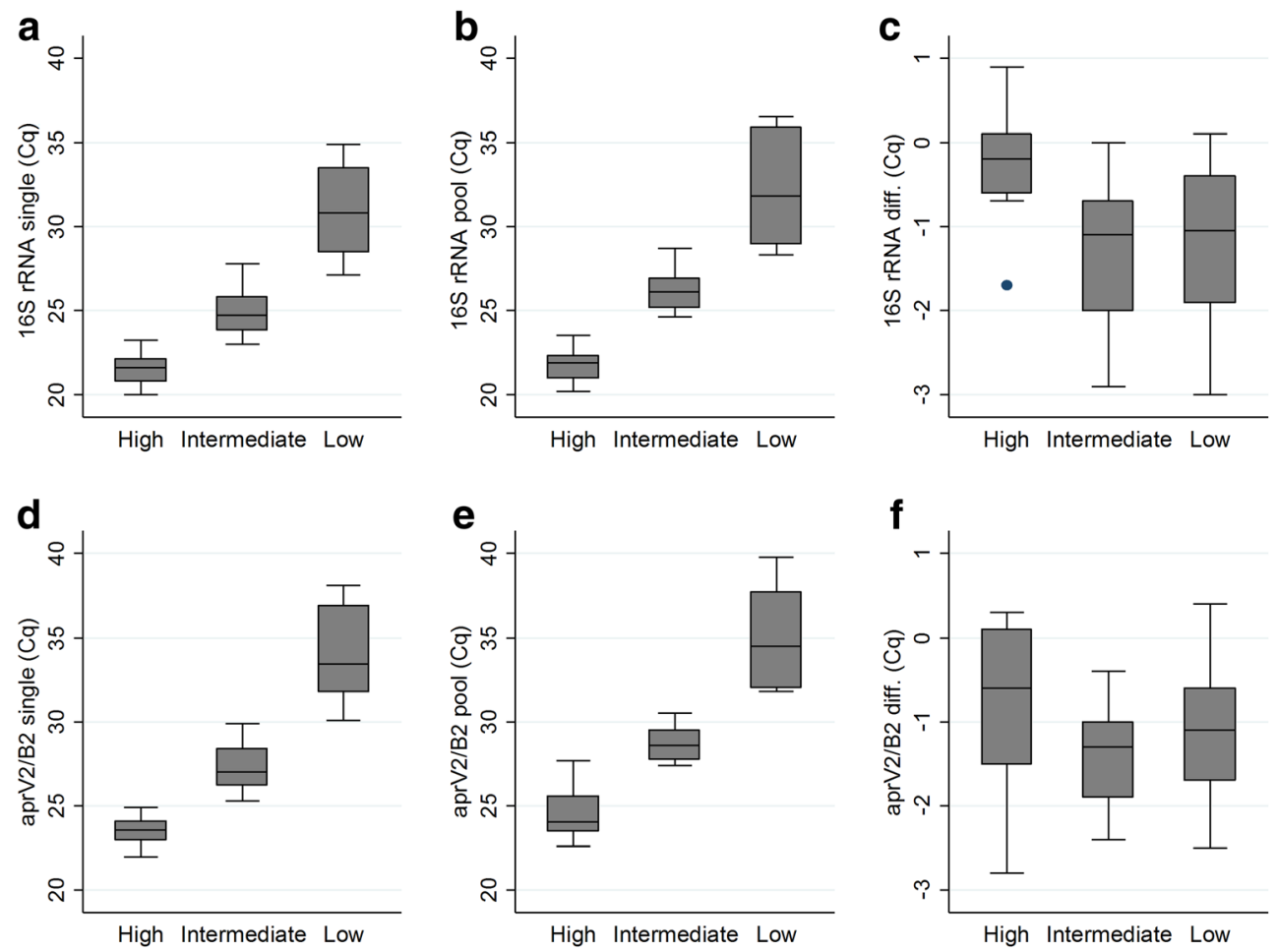

Fig. 1 Box-and-whisker plots of the quantification cycle $(\mathrm{Cq})$ values for individual ( $n=41$, Figs. a and d) and pooled samples (pools of five, the same positive samples as in the individual analysis but combined with four negative samples, Figs. $\mathrm{b}$ and e). Samples were analysed for $16 S r R N A$ (Figs. a, b and c) and aprV2/B2 (Figs. d, e and f) by real-time PCR assays to detect $D$. nodosus and to determine virulence, respectively. Figs. c and $\mathrm{f}$ show the difference in Cq-values for the individual and pooled analysis.
High, intermediate and low indicates the amount of $D$. nodosus bacteria in the samples as estimated by the aprV2/B2 PCR-assay (high $\mathrm{Cq}<25 n=10$; intermediate $\mathrm{Cq} 25-29.9 n=21$; and low $\mathrm{Cq} \geq 30 n=10$ ). The box shows the lower, median and upper quartiles, and the whisker shows the upper and lower adjacent values (1.5 inter-quartile range from the lower and upper quartiles, respectively). The dots are outliers 
individual and the pooled samples. A slight reduction of the analytical sensitivity for the pooled samples was seen as indicated by an increase of the Cq-values of the real-time PCR assays by approximately 1.1-1.2. However, it is unlikely that this is of any practical importance because the D. nodosus positive samples sent to the diagnostic laboratory at SVA, are seldom at the detection limit of the assays (Sara Åkerström, SVA, personal communication).

The use of only the aprV2/B2 assay for both detection and virulence determination of $D$. nodosus has been proposed by Stäuble et al. (2014a) but neither their assay nor the very similar one in this study, contains an internal amplification control, meaning that there is a risk of false negative results. Hence a separate assay, targeting the $16 \mathrm{~S} r R N A$ gene, was used for detection of D. nodosus in this study (Frosth et al. 2015). Moreover, using the $16 S r R N A$ assay as a complement to the $a p r V 2 / B 2$ assay means that isolates with possible mutations in the aprV2/B2 genes will not be missed. The possibility of finding variants of aprV2/B2 other than the two so far reported (Riffkin et al. 1995) is probably low, especially since D. nodosus is genetically highly conserved (Kennan et al. 2014). Nonetheless, running the two PCR-assays in parallel resulted in the discovery of a $D$. nodosus isolate with another amino acid in position 92 of AprV2/B2 than the described tyrosine and arginine (Frosth 2016). The $16 S$ rRNA and the aprV2/B2 PCR-assays can be run simultaneously on the same assay plate since they both use the same PCR-program.

None of the swab samples in this study contained virulent $D$. nodosus; which is not surprising since very few virulent D. nodosus have so far been found in Sweden (Frosth 2016). However, there is every reason to believe that the assay works equally well for virulent $D$. nodosus. In a previous evaluation, the aprV2 gene variant amplified and exhibited the same limit of detection as the aprB2 gene variant (Frosth 2016; Frosth et al. 2015). Furthermore, the aprV2/B2 PCR-assay has been successfully used on samples from UK sheep where the majority contained the aprV2 variant (Maboni et al. 2016).

A new swab was used for each foot that was sampled and the pooling was conducted at the laboratory. This avoids possible spread of the disease within the flock and ensures consistency in the sampling procedure. However, separate swabs were not used for the individual and pooled analysis, since that would have meant repeated sampling of the same foot which might influence the results. This approach also provides the opportunity for an individual analysis to be performed after the pooled analysis, for identification of specific positive animals in the pool.

In conclusion, our pooling procedure (five individual swabs) had the same diagnostic sensitivity as individual swab samples in the real-time PCR assays for the detection and virulence determination of $D$. nodosus. Even sub-clinical infections were able to be detected in the pooled PCR samples which is important for control of the disease. The method is a potentially useful diagnostic tool in footrot control programs where it can replace analysis of individual samples.

Acknowledgements We thank the owners of the participating sheep flocks for their willingness to contribute to this study and the veterinarians at the Farm and Animal Health for help with the clinical scoring and sampling. We also thank the Swedish Farmers' Foundation for Agricultural Research for financial support (grant number H1350161).

\section{Compliance with ethical standards}

Conflict of interest The authors declare that they have no conflict of interest.

Funding This study was funded by the Swedish Farmers' Foundation for Agricultural Research (grant number H1350161).

Ethical approval This study did not require official or institutional ethical approval.

Open Access This article is distributed under the terms of the Creative Commons Attribution 4.0 International License (http:// creativecommons.org/licenses/by/4.0/), which permits unrestricted use, distribution, and reproduction in any medium, provided you give appropriate credit to the original author(s) and the source, provide a link to the Creative Commons license, and indicate if changes were made.

\section{References}

Bennett GN, Hickford JG (2011) Ovine footrot: new approaches to an old disease. Vet Microbiol 148:1-7. doi:10.1016/j.vetmic.2010.09.003

Beveridge WIB (1941) Foot-rot in sheep: a transmissible disease due to infection with Fusiformis nodosus (n.Sp.). In: studies on its cause, epidemiology and control. Council for Scientific and Industrial Research, Melbourne (bulletin no. 140), pp 1-56

Egerton JR, Roberts DS, Parsonson IM (1969) The aetiology and pathogenesis of ovine foot-rot. I Histological Study of the Bacterial Invasion. J Comp Pathol 79:207-216

Farm and Animal Health (2016) Klövkontrollen. Sweden: Farm and Animal Health. Available from: http://www.gardochdjurhalsan. se/upload/documents/Dokument/Webbshop/Far/GoD_ klovkontroll 160404 korr.pdf. Accessed 12 Jan 2017

Frosth S (2016) Dichelobacter nodosus and footrot in Swedish sheep. Increased knowledge and improved laboratory diagnostics. Diss., Swedish University of Agricultural Sciences. http://pub.Epsilon. Slu.Se/13845/A3B2. Accessed 2 march 2017

Frosth S, König U, Nyman AK, Pringle M, Aspán A (2015) Characterisation of Dichelobacter nodosus and detection of Fusobacterium necrophorum and Treponema spp. in sheep with different clinical manifestations of footrot. Vet Microbiol 179:82-90. doi:10.1016/j.vetmic.2015.02.034

Frosth S, Slettemeås JS, Jørgensen HJ, Angen Ø, Aspan A (2012) Development and comparison of a real-time PCR assay for detection of Dichelobacter nodosus with culturing and conventional PCR: harmonisation between three laboratories. Acta Vet Scand 54:6. doi:10.1186/1751-0147-54-6

Green LE, George TR (2008) Assessment of current knowledge of footrot in sheep with particular reference to Dichelobacter nodosus and implications for elimination or control strategies for sheep in great Britain. Vet J 175:173-180. doi:10.1016/j.tvj1.2007.01.014 
Kennan RM et al. (2014) Genomic evidence for a globally distributed, bimodal population in the ovine footrot pathogen Dichelobacter nodosus. mBio 5 doi:10.1128/mBio.01821-14

Kennan RM, Han X, Porter CJ, Rood JI (2011) The pathogenesis of ovine footrot. Vet Microbiol 153:59-66. doi:10.1016/j.vetmic.2011.04.005

Maboni G, Frosth S, Aspán A, Tötemeyer S (2016) Ovine footrot: new insights into bacterial colonisation. Vet Rec 179. doi:10.1136 /vr.103610

Marshall DJ, Walker RI, Cullis BR, Luff MF (1991) The effect of footrot on body weight and wool growth of sheep. Aust Vet J 68:45-49. doi:10.1111/j.1751-0813.1991.tb03126.x

Moore LJ, Wassink GJ, Green LE, Grogono-Thomas R (2005) The detection and characterisation of Dichelobacter nodosus from cases of ovine footrot in England and Wales. Vet Microbiol 108:57-67. doi:10.1016/j.vetmic.2005.01.029

National Veterinary Institute (2016) Surveillance of infectious diseases in animals and humans in Sweden in 2015. Sweden: National Veterinary Institute (SVA) report series no 34, ISSN 1654-7098. Available from: http://www.sva.se/smittlage/zoonosrapporter. Accessed 12 Jan 2017

Riffkin MC, Wang LF, Kortt AA, Stewart DJ (1995) A single amino-acid change between the antigenically different extracellular serine proteases V2 and B2 from Dichelobacter nodosus. Gene 167:279283. doi:10.1016/0378-1119(95)00664-8

Stewart DJ, Claxton PD (1993) Ovine foot rot: clinical diagnosis and bacteriology. In: Corner LA, Bagust TJ (eds) Australian standard diagnostic techniques for Animal diseases. CSIRO, East Melbourne, pp $1-27$

Stewart DJ, Peterson JE, Vaughan JA, Clark BL, Emery DL, Caldwell JB, Kortt AA (1986) The pathogenicity and cultural characteristics of virulent, intermediate and benign strains of Bacteroides nodosus causing ovine foot-rot. Aust Vet J 63:317-326. doi:10.1111 jj.1751-0813.1986.tb02875.x

Stäuble A, Steiner A, Frey J, Kuhnert P (2014a) Simultaneous detection and discrimination of virulent and benign Dichelobacter nodosus in sheep of flocks affected by foot rot and in clinically healthy flocks by competitive real-time. PCR J Clin Microbiol 52:1228-1231. doi:10.1128/JCM.03485-13

Stäuble A, Steiner A, Normand L, Kuhnert P, Frey J (2014b) Molecular genetic analysis of Dichelobacter nodosus proteases AprV2/B2, $\mathrm{AprV5} / \mathrm{B} 5$ and BprV/B in clinical material from European sheep flocks. Vet Microbiol 168:177-184. doi:10.1016/j. vetmic.2013.11.013 